\title{
Dosering av faste legemidler før elektive operasjoner
}

\author{
Pasienters faste medisiner kan ha spesielt gunstige eller uheldige \\ effekter $\mathrm{i}$ en perioperativ situasjon. Før elektive inngrep må det derfor \\ i samarbeid med anestesiolog gjøres individuelle vurderinger av medi- \\ kamentbruk før, under og etter inngrepet.
}

Se også kunnskapsprøve på www.tidsskriftet.no/quiz

\author{
Johan Ræder \\ johan.rader@medisin.uio.no \\ Avdeling for anestesiologi \\ Oslo universitetssykehus, Ullevål \\ og \\ Institutt for klinisk medisin \\ Det medisinske fakultet \\ Universitetet i Oslo \\ Randi Støen \\ Avdeling for anestesiologi \\ Oslo universitetssykehus, Ullevål
}

I utgangspunktet vil pasienter ha nytte av sine medisiner i ordinær dosering gjennom et perioperativt forløp. Imidlertid kan en del medikamenteffekter, bl.a. fysiologiske forandringer og interaksjoner med spesielle perioperative medikamenter, være uheldige. Motsatt er enkelte medikamenter spesielt uheldig å seponere i forbindelse med et inngrep, mens noen medikamenter er det hensiktsmessig å starte opp med, bruke midlertidig eller øke dosen på for å redusere perioperativ risiko.

Denne oversikten omtaler praksis ved elektive operasjoner, inkludert dagkirurgi, samt inngrep eller prosedyrer som krever regional eller generell anestesi (tab 1) (1-3). Selv om temaet omtales i de fleste lærebøker, er det rom for en viss bruk av skjønn, da det er gjort få studier (1-3).

Grunnlaget for artikkelen er litteratursøk i PubMed og forfatternes vurderinger basert på egne erfaringer fra klinisk praksis, kurs, kongresser og litteratur om temaet. Artikkelformatet tilsier at vi har måttet begrense omtalen av medikamentinteraksjoner og utelate omtale av enkelte medikamenter og medikamentgrupper.

\section{Faste rutiner og praktiske forhold}

Ved elektiv kirurgi kan peroral medikasjon, for eksempel morgenmedisin, gis med litt vann frem til én time før anestesistart (2). Etter de fleste inngrep vil ventrikkel- og tarmfunksjon komme i gang igjen i løpet av få timer, slik at ordinær kveldsdose vanlig- vis kan gis. Hvis ikke, må behovet for parenteral dosering vurderes. Rektale stikkpiller er et alternativ for enkelte medikamenter, men absorpsjonen er variabel.

Det er en god regel å be pasientene ta med sine faste medisiner til sykehuset, både for å sikre seg at man vet hva pasienten tar og fordi en vanlig sengepost ikke alltid har tilgang til spesielle medisiner.

\section{Antidiabetika}

Hovedhensynet perioperativt er å unngå hypoglykemi, noe som kan være fatalt hvis pasienten er i generell anestesi og ikke kan rapportere symptomer. Diabetikere skal forholde seg normalt til både næringsinntak og bruk av antidiabetika, inkludert insulin, frem til midnatt dagen før operasjonen (3). Etter dette skal de verken innta karbohydrater eller ta antidiabetika. Disse pasientene bør prioriteres tidlig på operasjonsprogrammet. Blodsukkeret kontrolleres tidlig operasjonsdagen, og en individuell plan legges for videre blodsukkermålinger, dosering av insulin og/eller intravenøs glukose.

\section{Medikamenter \\ som kan påvirke hemostasen}

Under kirurgiske inngrep er god hemostase viktig og ofte helt avgjørende for et vellykket resultat. Etter kirurgi vil kroppens hemostasemekanismer være aktivert, noe som i tillegg til eventuelt sengeleie disponerer for tromboemboliske komplikasjoner. Perioperativ bruk av medikamenter som påvirker hemostasen, innebærer en avveining mellom blødningsfare og trombose, vurdert mot pasientens generelle helse og type kirurgi (4-6).

Ved fare for perioperativ blødning anbefales det ofte at tradisjonelle ikke-steroide antiinflammatoriske preparater (NSAID) seponeres 1-3 dager før kirurgi, avhengig av halveringstiden for det aktuelle preparatet. Midlertidig seponering på grunn av blødningsfare er ikke nødvendig for selektive COX-2-hemmere, da disse ikke har blodplatehemmende effekt. Både tradisjonelle
NSAID-midler og COX-2-hemmere bør seponeres 1-3 dager preoperativt hvis man er redd for uheldige renale effekter, spesielt hos eldre og ved mulighet for større blødning, hypovolemi eller hypotensjon (4).

Acetylsalisylsyre hemmer blodplatenes syklooksygenase irreversibelt og gir moderat øt blødningstendens av noen dagers varighet. Det har vært vanlig å anbefale seponering av acetylsalisylsyre 5-10 dager før kirurgi der økt blødningstendens er spesielt ugunstig. Imidlertid anbefales det i nyere retningslinjer at medikasjonen fortsetter frem til operasjonen hvis indikasjonen er sterk, som ved gjennomgått tromboembolisme samt ved tidligere koronarkirurgi eller perifer karkirurgi $(4,7)$. Særlig viktig er det alltid å opprettholde acetylsalisylsyremedikasjonen hos pasienter med arteriell stent. Mange av disse behandles også med en adenosindifosfat (ADP)-reseptorhemmer (f.eks. klopidogrel, prasugrel, tiklopidin). Håndtering av denne medikasjonen vil avhenge av type stent, tid siden innsetting og planlagt inngrep. Sjablongmessig seponering av platehemmere må ikke forekomme hos pasienter med stent.

Anestesiolog, kirurg, kardiolog og eventuelt hematolog bør konsulteres i slike tilfeller. Når metallstent er innlagt senere enn 6-12 uker før operasjonen, skal som hovedregel klopidogrel og andre ADP-reseptorhemmere kontinueres. Er det lenger enn 6-12 uker siden innleggelse av metallstent, kan de seponeres fem dager preoperativt. Ved medikamentavgivende stent skal platehemmere ikke seponeres det første året etter innleggelse. Det anbefales at dipyridamol tas til og med dagen før operasjonen dersom ikke spesielle forhold hos pasienten eller den kirurgiske prosedyren taler imot $(6,8)$.

\section{Hovedbudskap}

- Fullstendige opplysninger om alle pasientens medikamenter, herunder naturmedisiner, er viktig å få frem preoperativt

- For de fleste medikamenter gjelder enkle hovedregler knyttet til perioperativ bruk, men for enkelte medikamenter må det legges en individuell plan

- Medikamenter som påvirker hemostase, blodtrykk, blodsukker og psyke må vurderes spesielt 
Tabell 1 Kort oversikt over medikamenter og anbefalte tiltak (1-3)

\begin{tabular}{|c|c|}
\hline Medikament & Anbefalinger \\
\hline Antidiabetika & Seponeres kl 24 kvelden før operasjonen \\
\hline \multicolumn{2}{|l|}{ Medikamenter m/effekt på hemostasen $(+/ \div)$} \\
\hline Ikke-steroide antiinflammatoriske legemidler (NSAIDs) & Ev. seponere, 1-3 dager preoperativt \\
\hline coX-2-hemmere & Ev. seponere, 1-3 dager preoperativt Igir ikke $\varnothing$ \\
\hline Acetylsalisylsyre & Ev. seponere flere dager før, men beholdes ved \\
\hline Dipyramidol & Primært kontinuere til og med dagen før operas \\
\hline Klopidogrel og andre tienopyridiner & Ev. seponere 5 dager preoperativt, individuell vu \\
\hline Warfarin & Seponere, INR-verdi måles tre dager før inngre \\
\hline \multicolumn{2}{|l|}{ Antihypertensiver } \\
\hline ACE-hemmere & Utelate kvelden før og selve operasjonsdagen \\
\hline Angiotensin II-antagonist & Utelate kvelden før og selve operasjonsdagen \\
\hline Betablokkere & Kontinuere, ev. starte opp > 1 uke preoperativt \\
\hline Alfa-2-agonister & Kontinuere \\
\hline Kalsiumantagonister & Ev. seponere preoperativt på operasjonsdagen \\
\hline Diuretika & Ev. seponere preoperativt på operasjonsdagen \\
\hline Statiner & Kontinuere, ev. starte opp $>1$ uke preoperativt \\
\hline Glukokortikoider & Kontinuere, ev. øke dosering \\
\hline Antastmatika & Kontinuere, ev. ta ekstra preoperative doser \\
\hline Antiepileptika & Kontinuere som normalt \\
\hline Thyreiodeamidler & Kontinuere som normalt \\
\hline Midler mot erektil dysfunksjon & Seponere $>36$ timer preoperativt \\
\hline Øyedråper & Kontinuere \\
\hline \multicolumn{2}{|l|}{ Analgetika } \\
\hline Opioider & Kontinuere \\
\hline Paracetamol & Kontinuere \\
\hline NSAID-midler/COX-2-hemmere & Se ovenfor \\
\hline \multicolumn{2}{|l|}{ Psykofarmaka } \\
\hline Sovemedisin & Kontinuere \\
\hline Benzodiazepiner & Kontinuere \\
\hline Antidepressiver & Individuell vurdering \\
\hline Nevroleptika & Individuell vurdering \\
\hline Naturmedisiner & Seponere 1-2 uker preoperativt \\
\hline Medisinske hjelpemidler & Kontinuere og ta med til sykehuset \\
\hline
\end{tabular}

Vitamin K-antagonister (warfarin) bør vanligvis seponeres før kirurgi. Tidspunkt avhenger av indikasjonen for antikoagulasjon, type planlagt kirurgi og INR-verdi. Denne bør ikke bli for lav hvis dette kan få alvorlige konsekvenser, som ved mekanisk hjerteventil, atrieflimmer og tidligere tromboembolisme. INR-verdien bør måles tre dager før planlagt inngrep, og seponeringstidspunkt bestemmes ut fra verdien. Ved INR 2,5-3,0 bør warfarin seponeres 1-2 døgn før operasjon, og ved INR 3,0-3,5 bør seponering skje 2-3 døgn før operasjon (6). De fleste kirurgiske inngrepene kan utføres med INR 1,8-2,2 operasjonsdagen. Hvis INR $<1,8$ dagen før eller selve operasjonsdagen, gis eventuelt dalteparin eller enoksaparin subkutant (6). Doseringen vil avhenge både av INR-nivå, tromboserisiko, kirurgiens omfang og eventuelle trombosekonsekvenser.

\section{Antihypertensiver}

Antihypertensiver kan, i kombinasjon med regional eller generell anestesi, gi problemer med lavt blodtrykk (8). De fleste anestesiologer velger derfor ikke å gi angiotensinkonvertasehemmere (ACE-hemmere) eller angiotensin II-reseptorantagonister kvelden før og samme morgen som inngrepet er planlagt.

Betablokkere reduserer hjertets frekvens og kontraktilitet, og altså oksygenbehovet, slik at de beskytter mot perioperativ kardial iskemi og infarkt. De har også en antiinflammatorisk og plakkstabiliserende effekt som er gunstig ved perioperative belastninger. Dette må veies mot faren for hypotensjon og bradykardi, som kan resultere i cerebrovaskulær iskemi eller infarkt. Det er viktig å unngå seponering eller perioperativt opphold i betablokade, fordi dette kan gi forbigående økt tendens til hypertensjon, takykardi og arytmi (tilbakejusteringseffekt (rebound-fenomen)). Stabil effekt tilstrebes, og behandlingsmål er hvilepuls $60-70$ slag/ min, eventuelt lavere ved god toleranse, og systolisk blodtrykk $>100 \mathrm{~mm} \mathrm{Hg}$. Pasienter som ikke bruker betablokker, men der indikasjon foreligger pga. angina eller arytmi, bør vurderes for oppstart av betablokade minst én uke, helst fire uker, før inngrepet (8). Det samme gjelder pasienter som skal til inngrep med høy risiko for kardiale komplikasjoner, slik som koronarkirurgi, større kar-, thorax- eller bukkirurgi.

Alfa-2-agonister, f.eks. klonidin, kan gi tilbakejusteringseffekt ved seponering og skal derfor kontinueres gjennom hele det perioperative forløpet, peroralt eller intravenøst (7).

Kalsiumantagonister kan beskytte mot arytmier og koronar iskemi og blir vanligvis kontinuert perioperativt. De kan utelates selve operasjonsdagen hvis peroperativ 
hypotensjon anses spesielt ugunstig. Det samme gjelder for diuretika, der det ofte er logisk å utelate preoperativ morgendose fordi pasienten er fastende og allerede lett dehydrert.

\section{Kolesterolsenkende midler}

Statiner har antiinflammatoriske og vasoaktive egenskaper som er gunstige og risikoreduserende med tanke på perioperative vaskulære komplikasjoner, også for pasienter uten hyperlipidemi (8). Derfor skal statiner, om mulig, administreres gjennom hele det perioperative forløpet. Hos pasienter som skal til inngrep med høy risiko og/eller har alvorlig kardiovaskulær sykdom, anbefales det å starte statinbehandling minst en uke før inngrepet. Siden disse medikamentene foreløpig ikke kan administreres parenteralt, anbefales statiner med lang halveringstid og eventuelt depotformulering til bruk preoperativt (7)

\section{Analgetika og psykofarmaka}

Med unntak av spesielle forhold knyttet til NSAID-preparater og acetylsalisylsyre bør analgetika tas som vanlig preoperativt. Dette gjelder også pasienter med kronisk smerte og pasienter som får legemiddelassistert rehabilitering etter narkotikamisbruk (9). Pasienter som bruker sovemedisin eller lette sedativer, kan ta disse kvelden før et inngrep eller som premedikasjon ved behov.

Individuelle hensyn må tas for andre psykotrope medisiner, der risikoen for interaksjoner og alvorlige bivirkninger må veies mot faren for psykisk destabilisering og andre seponeringseffekter. Diskusjon med behandlende psykiater kan være nødvendig. Dersom trisykliske antidepressiver skal seponeres, må det skje gradvis. Selektive serotoninreopptakshemmere (SSRI) seponeres oftest ikke, men økt blødningstendens må vurderes ved kombinasjon med acetylsalisylsyre eller NSAID-preparater. Antipsykotiske medikamenter beholdes vanligvis, men klozapin må vurderes spesielt hos sirkulatorisk ustabile pasienter (10).

\section{Andre legemidler}

Bruk av glukokortikoider i døgndoser tilsvarende $5 \mathrm{mg}$ prednisolon eller mer fører til reduksjon i binyrebarkens normale stressrespons (3). Det er derfor vanlig å gi en ekstra dose kortikosteroid peroperativt til pasienter som bruker slike medisiner fast.

Astmatikere kan bruke kombinasjoner av systemisk og inhalert medikasjon, enten fast, periodevis eller som anfallsprofylakse. Fast medikasjon bør tas som vanlig. For dem som bruker medikasjon ved behov, er det fornuftig å ta inhalasjonsmedikasjon forebyggende de siste 12-24 timene før inngrepet. Inhalasjonsmedisin skal tas med til sykehuset, og en ekstra dose kan tas preoperativt.

Antiepileptika tas som normalt, til og med operasjonsdagen. Det samme gjelder thyreoideamedikasjon. Det bør være bekreftet at pasienten er eutyreot.

Legemidler mot erektil dysfunksjon anbefales seponert minst 36 timer før kirurgi på grunn av uheldige kardiovaskulære effekter (3).

Pasienten bør ta med sine egne øyedråper, og korrekt administrering er viktig.

\section{Naturmedisiner}

Hovedregelen er at disse skal seponeres 1-2 uker før operasjonen $(1,3)$. Enkelte naturmedisiner inneholder ukjent type og mengde av stoffer som kan påvirke koagulasjon, blødning og blodtrykk, og som i enkelte tilfeller kan medføre farlige interaksjoner med anestesimidler (11). Hvis seponering er umulig, f. eks. ved øyeblikkelig hjelp-situasjoner eller manglende pasientsamarbeid, er det viktig at pasienten tar med de aktuelle midlene til sykehuset i originalforpakning, slik at anestesilegen kan vurdere eventuelle tiltak

\section{Medisinsk utstyr}

Pasienten bør ta med hjelpemidler og utstyr som brukes til vanlig, f.eks. inhalator eller insulinpenn. Pasienter som bruker CPAPmaske mot søvnapné, bør ha med sin vante maske for bruk postoperativt og om natten Pasienter med pacemaker eller hjertestarter (ICD) bør få denne kontrollert før inngrepet, og journalførte opplysninger om utstyrstype og spesifikasjoner kan være nyttig.

\section{Konklusjon}

Man bør foreta en individuell vurdering av perioperativ dosering av faste legemidler når pasienter skal opereres. Viktige faktorer er pasientens generelle helse, indikasjon for legemiddelbehandling og spesielle forhold knyttet til planlagte kirurgiske inngrep. Særlig oppmerksomhet må vies medikamenter som påvirker hemostase, blodtrykk, blodsukker og psyke. For de fleste øvrige medikamenter gjelder at vanlig dosering opprettholdes perioperativt.

\section{Johan Ræder (f. 1954)}

er spesialist i anestesiologi, professor II i anestesiologi og seksjonsoverlege ved Avdeling for anestesiologi, Oslo universitetssykehus, Ullevål. Han har bl.a. forsket på problemstillinger knyttet til dagkirurgi og anestesiologi samt anestesiologisk farmakologi og smerter etter operasjoner

Ingen oppgitte interessekonflikter.

\section{Randi Støen (f. 1951)}

er spesialist i anestesiologi og overlege ved Avdeling for anestesiologi, Oslo universitetssykehus, Ullevål.

Ingen oppgitte interessekonflikter.

Litteratur

1. Miller RD Miller's anesthesia. 7. utg. Philadelphia, PA: Churchill Livingstone, 2009: 763-80.

2. Raeder J. Clinical ambulatory anaesthesia. Cambridge: Cambridge University Press, 2010.

3. UpToDate. Perioperative medication management www.uptodate.com/contents/perioperativemedication -management? source=search result\&selectedTitle=1\%7E150 (5.8.2011).

4. Hirsh J, Guyatt G, Albers GW et al. Antithrombotic and thrombolytic therapy: American College of Chest Physicians Evidence-Based Clinical Practic Guidelines (8th Edition). Chest 2008; 133 (suppl) 110S-2S.

5. Breivik H, Bang U, Jalonen J et al. Nordic guidelines for neuraxial blocks in disturbed haemostasis from the Scandinavian Society of Anaesthesiology and Intensive Care Medicine. Acta Anaesthesiol Scand 2010; 54: 16-41.

6. Marevan og blodplatehemmere ved kirurgi. www.nycomed.com/no/search/?q=marevan $\%$ 20og\%20blodplatehemmere\&filter=0 (5.8.2011)

7. Stokland O. Kardiovaskulær intensivmedisin. Oslo: Cappelen Damm Akademisk, 2010.

8. Sellevold OF. Stenseth R. Ikke-kardial kirurgi hos hjertesyke pasienter. Tidsskr Nor Legeforen 2010 130: $623-7$

9. Fredheim OM, Nøstdahl T, Nordstrand B et al. Behandling av akutte smerter under legemiddelassistert rehabilitering. Tidsskr Nor Legeforen 2010: 130: $738-40$

10. Huyse FJ, Touw DJ, van Schijndel RS et al. Psychotropic drugs and the perioperative period: a proposal for a guideline in elective surgery. Psychosomatics 2006: 47: 8-22.

11. Solhaug V, Nergård CS. Interaksjoner mellom warfarin og naturmidler. Tidsskr Nor Lægeforen 2010; 130: $1252-4$

Mottatt 29.9. 2010, første revisjon innsendt 15.4 . 2011, godkjent 22.12. 2011. Medisinsk redaktør Mette Sagsveen. 